Review Article

\title{
Clinical Features, Treatment, and Surveillance of Hyperparathyroidism-Jaw Tumor Syndrome: An Up-to-Date and Review of the Literature
}

\author{
Francesca Torresan and Maurizio Iacobone $(\mathbb{D}$ \\ Endocrine Surgery Unit, Department of Surgery, Oncology and Gastroenterology, University of Padova, Via Giustiniani 2, \\ 35128 Padova, Italy \\ Correspondence should be addressed to Maurizio Iacobone; maurizio.iacobone@unipd.it
}

Received 5 September 2019; Accepted 11 November 2019; Published 18 December 2019

Guest Editor: Vito Guarnieri

Copyright (C) 2019 Francesca Torresan and Maurizio Iacobone. This is an open access article distributed under the Creative Commons Attribution License, which permits unrestricted use, distribution, and reproduction in any medium, provided the original work is properly cited.

Hyperparathyroidism-jaw tumor (HPT-JT) syndrome is an autosomal dominant disorder characterized by parathyroid tumors in association with fibro-osseous jaw tumors and uterine and renal lesions. HPT-JT syndrome is caused by germline mutations of the cell division cycle 73 (CDC73) gene that encodes the parafibromin, a 531-amino acid protein with antiproliferative activity. Primary hyperparathyroidism is the main finding of HPT-JT syndrome, usually caused by a single-gland parathyroid involvement ( $80 \%$ of cases), at variance with other variants of hereditary hyperparathyroidism, in which a multiglandular involvement is more frequent. Moreover, parathyroid carcinoma may occur in approximately $20 \%$ of cases. Surgery is the treatment of choice for primary hyperparathyroidism, but the extent of surgery remains controversial, varying between bilateral neck and focused exploration, with subtotal or limited parathyroidectomy. Recently, more limited approaches and parathyroid excisions have been suggested in order to decrease the risk of permanent hypoparathyroidism, the main surgical morbidity following more extensive surgical approaches. Ossifying fibromas of the mandible or maxilla may present only in a minority of cases and, even if benign, they should be surgically treated to avoid tumor growth and subsequent functional limitations. Benign and malignant uterine involvement (including leiomyomas, endometrial hyperplasia, adenomyosis, multiple adenomyomatous polyps, and adenosarcomas) is the second most common clinical feature of the syndrome, affecting more than $50 \%$ of CDC73-carrier women. Genetic testing should be performed in all family members of affected individuals, in young patients undergoing surgery for primary hyperparathyroidism, or in presence of other associated tumors, allowing early diagnosis and prompt treatment with more tailored surgery. Moreover, CDC73 mutation carriers should be also periodically screened for primary hyperparathyroidism and the other associated tumors. The present review was aimed to summarize the main clinical features of HPT-JT syndrome, focusing on genetic screening and surgical treatment, and to revise the available literature.

\section{Introduction}

Hyperparathyroidism-jaw tumor syndrome (HPT-JT) (OMIM\#145001) is a rare autosomal dominant disorder with incomplete penetrance characterized by the development of parathyroid tumors, ossifying fibromas of the mandible and maxilla, cystic and neoplastic renal abnormalities, and hyperplastic and neoplastic uterine involvement $[1,2]$.

HPT-JT syndrome is caused by germline mutations of the $C D C 73$ gene that encodes the parafibromin, a ubiquitously expressed, predominantly nuclear protein with antiproliferative properties [3-6].

Despite the nomenclature of the syndrome, jaw tumors may be found only in approximately one third of cases, while the most common, and sometimes the only feature of HPT$\mathrm{JT}$, is primary hyperparathyroidism (pHPT). At variance with other forms of hereditary pHPT in which parathyroid tumors are generally benign, HPT-JT is associated with a higher prevalence of atypical adenomas and carcinomas $[7,8]$. 
Genetic testing is required to confirm the hereditary nature of pHPT in HPT-JT, and it is crucial for the optimal clinical and surgical management of the affected individuals; moreover, a molecular genetic testing should be obtained in at risk relatives in order to identify the gene carriers as early as possible to start surveillance and early treatment [9].

The aim of this review is to summarize the current knowledge on HPT-JT syndrome including clinical features, genetic, and treatments and to revise the available literature.

\section{Etiology and Diagnosis}

HPT-JT is linked to germline-inactivating mutations in the tumor suppressor gene CDC73 (formerly HRPT2), which is comprised of 17 exons on chromosome 1q31.2 and encodes for the predominantly nuclear, 531-amino acid protein, parafibromin [10]. Parafibromin is ubiquitously expressed in a variety of human tissues, including kidney, liver, stomach, renal cortex tubules, and the pars intermedia of the hypophysis [11].

Parafibromin is associated with other proteins in the polymerase-associated factor (PAF1) and induces the downregulation of cyclin D1 expression and direct interaction with $\beta$-catenin, resulting in the activation of transcription of target genes. Studies of the PAF1 complex in yeast and Drosophila, as well as in mammalian cells, have revealed that parafibromin, as part of the PAF1 complex, induces histone modification, transcription elongation, and chromatin remodeling [12-14].

About $75 \%$ of HPT-JT patients have germline CDC73 mutations within the coding region, and the majority (>80\%) are frameshift or nonsense mutations that determine the functional loss of parafibromin by causing a premature truncation of this protein or a rapid loosing of the translated protein via nonsense-mediated mRNA decay. Therefore, the expression of parafibromin is completely lost in HPT-JTassociated tumor tissues. Immunohistochemical staining of parafibromin in parathyroid tumors and other HPT-JTassociated tumors is an indirect method to recognize HPTJT syndrome patients. The remaining $25 \%$ of HPT-JT patients may have abnormalities in CDC73 promoter regions, whole exon or gene deletions, mutations in unidentified genes, or epigenetic modifications [15].

As in all tumor suppressor genes, the first mutation is usually inherited by one of the parents or, in very rare cases, developed de novo at embryo level; the second allele-inactivating mechanism is a novel acquired somatic mutation or a loss of heterozygosity in HPT-JT tumor-related tissues, consistent with Knudson's two-hit hypothesis [7-16].

Even in presence of a CDC73 mutation, the penetrance of pHPT is incomplete and no genotype-phenotype correlations have been fully established to date. However, it has been suggested that missense mutations are more likely to be associated with the disease without typical associated features (familial isolated pHPT), whereas mutations causing gross parafibromin disruption are more likely associated with the classical HPT-JT phenotype [9].

The diagnosis of HPT-JT must be confirmed by genetic testing. The screening for CDC73 germline mutations is indicated in presence of familial pHPT, in case of $\mathrm{pHPT}$ with young age onset (<40 years), multiglandular involvement, cystic, atypical, or malignant parathyroid involvements, or in presence of coexistence ossifying jaw fibroma, renal, or uterine tumors $[9,17]$. As in the original description of HPTJT syndrome, where it was characterized as cystic parathyroid adenomatosis, the adenomas may be cystic, either with micro- or macrocysts, and similar cystic changes can also be present in the normal parathyroid glands in these patients [18].

Following the initial diagnosis, the associated jaw tumors and renal and uterine lesions should be systematically searched [3-6].

Genetic screening for identifying the gene carrier and/or affected family members should be performed in all family members to start a specific HPT-JT screening program [19]. In CDC73 mutation carrier families, the screening should be performed also in children before the age of 10 since malignant $\mathrm{pHPT}$ has been sometimes described at very early age.

\section{Clinical Features}

3.1. $\mathrm{pHPT}$. $\mathrm{pHPT}$ is the main finding of HPT-JT syndrome and is found in almost $100 \%$ of mutation carriers typically in late adolescence or early adulthood. The earliest reported age of hypercalcemia is seven years [20]. The median age of diagnosis of pHPT reported was 27 years (range 12-58) [21], and the mean age ranged between 32 years and 36 years $[4,22]$. In a report of a three large kindred, CDC73related pHPT occurred in $87.5 \%$ of cases among patients older than 20 years [9], while penetrance of $\mathrm{pHPT}$ in a Dutch population was shown to increase with age $(8 \%, 53 \%$, and $75 \%$ at ages 25,50 , and 70 , respectively) [22]. To date, 154 HPT-JT kindreds have been reported in the literature (Table 1), including 365 patients affected by pHPT. At variance with other forms of hereditary PHPT, in HPT-JT, a single-gland parathyroid involvement has been reported more frequently $(86.1 \%)$. Multiglandular involvement occurs rarely at initial surgery (13.9\% of cases); recurrences of pHPT may occur metachronously in $20 \%$ of cases. At pathology, a single benign parathyroid adenoma is usually found; however, parathyroid carcinoma may be found in $23 \%$ of cases [2-82].

pHPT is usually mild and/or asymptomatic, but, in the case of parathyroid carcinoma, severe hypercalcemic crises may occur [83]. Hence, in presence of abnormal high serum calcium concentration $(>12 \mathrm{mg} / \mathrm{dL})$ and iPTH levels $(>3$ times the upper limit of normal) and parathyroid lesions larger than $3 \mathrm{~cm}$, parathyroid carcinomas should be suspected, even if nonfunctioning parathyroid malignancy may very rarely occur in CDC73-related disorder [35, 82]. Moreover, parathyroid carcinoma can present as palpable neck mass associated with hoarseness, difficulty speaking or swallowing, muscle weakness, nausea/vomiting, altered mental status, bone pain, and/or pathologic bone fractures $[7,17,22,23,38]$.

Given the rarity of the disease and the heterogeneity of the phenotype, the optimal surgical approach to CDC73-related 
TABLE 1: Review of the literature focusing on HPT-JT syndrome.

\begin{tabular}{|c|c|c|c|c|c|c|c|c|c|}
\hline Author (year) & $\begin{array}{l}\text { Kindred } \\
\quad(n=)\end{array}$ & $\begin{array}{c}\mathrm{pHPT} \\
(n=)\end{array}$ & $\begin{array}{l}\text { Single-gland } \\
\text { pHPT }(n=)\end{array}$ & $\begin{array}{l}\text { Synchronous } \\
\text { multiglandular } \\
\text { pHPT }(n=)\end{array}$ & $\begin{array}{l}\text { Recurrences } \\
\qquad(n=)\end{array}$ & $\begin{array}{l}\text { Parathyroid } \\
\text { carcinoma } \\
(n=)\end{array}$ & $\begin{array}{c}\text { Jaw } \\
\text { tumor } \\
(n=)\end{array}$ & $\begin{array}{c}\text { Renal } \\
\text { lesions } \\
(n) \\
\end{array}$ & $\begin{array}{c}\text { Uterine } \\
\text { lesions } \\
(n)\end{array}$ \\
\hline Carpten et al. (2002) [7] & 14 & 66 & NA & NA & NA & 11 & 30 & 18 & NA \\
\hline Shattuck et al. (2003) [23] & 3 & 3 & NA & NA & NA & 3 & NA & NA & NA \\
\hline Howell et al. (2003) [24] & 3 & 7 & NA & NA & 0 & 3 & 0 & 0 & NA \\
\hline Simonds et al. (2004) [25] & 1 & 4 & 4 & 0 & 0 & 1 & 0 & 0 & NA \\
\hline Cetani et al. (2004) [17] & 2 & 4 & 3 & 1 & NA & 0 & 0 & 0 & NA \\
\hline $\begin{array}{l}\text { Villablanca et al. (2004) } \\
\text { [26] }\end{array}$ & 2 & 9 & 7 & 2 & 3 & 0 & 0 & 0 & NA \\
\hline Cavaco et al. (2004) [27] & 6 & 9 & 5 & 1 & 0 & 0 & 2 & 2 & NA \\
\hline Howell et al. (2004) [28] & 1 & 2 & 2 & 0 & NA & 0 & 1 & NA & NA \\
\hline Bradley et al. (2005) [2] & 2 & 9 & NA & NA & NA & 2 & 11 & 0 & 6 \\
\hline Moon et al. (2005) [29] & 1 & 2 & 2 & 0 & NA & 2 & 1 & NA & NA \\
\hline Gimm et al. (2006) [30] & 1 & 3 & 1 & 1 & 1 & 1 & NA & NA & NA \\
\hline Mizusawa et al. (2006) [31] & 3 & 7 & 6 & 0 & 1 & 1 & 1 & 0 & 0 \\
\hline Aldred et al. (2006) [32] & 1 & 3 & 3 & 0 & 0 & 0 & 2 & NA & NA \\
\hline Bradley et al. (2006) [33] & 5 & 5 & 4 & 1 & NA & 0 & 2 & 0 & 1 \\
\hline Juhlin et al. (2006) [34] & 1 & 1 & 1 & NA & NA & 0 & NA & NA & NA \\
\hline Guarnieri et al. (2006) [35] & 1 & 4 & 4 & 0 & 1 & 1 & NA & 0 & 2 \\
\hline Kelly et al. (2006) [8] & 1 & 3 & 2 & 1 & 2 & 2 & NA & NA & NA \\
\hline $\begin{array}{l}\text { Yamashita et al. (2007) } \\
\text { [36] }\end{array}$ & 1 & 1 & 1 & 0 & 0 & 0 & 1 & NA & NA \\
\hline Cetani et al. (2007) [37] & 1 & 1 & 1 & 0 & 1 & 0 & 0 & 0 & NA \\
\hline Cetani et al. (2007) [38] & 2 & 3 & NA & NA & NA & 3 & NA & NA & NA \\
\hline Raue et al. (2007) [39] & 1 & 2 & 1 & 1 & NA & 1 & 1 & NA & NA \\
\hline Cetani et al. (2008) [40] & 1 & 1 & 1 & 0 & NA & 1 & 0 & NA & NA \\
\hline Sarquis et al. (2008) [41] & 3 & 11 & 5 & 6 & 6 & 1 & 1 & 4 & 5 \\
\hline Guarnieri et al. (2008) [42] & 3 & 3 & 3 & 0 & 1 & 3 & 0 & 3 & 3 \\
\hline Howell et al. (2009) [43] & 1 & 1 & 1 & 0 & 0 & NA & NA & NA & NA \\
\hline Silveira et al. (2008) [44] & 1 & 9 & 3 & 6 & 6 & 1 & 0 & 4 & 5 \\
\hline Schmidt et al. (2009) [45] & 1 & 1 & 1 & 0 & 0 & 0 & 1 & NA & NA \\
\hline Rekik et al. (2010) [46] & 1 & 1 & 1 & 0 & 0 & 0 & 1 & 0 & 1 \\
\hline Panicker et al. (2010) [47] & 1 & 5 & NA & NA & NA & 0 & 1 & 0 & 1 \\
\hline Veiguela et al. (2010) [48] & 1 & 7 & NA & NA & NA & 1 & 3 & 0 & 2 \\
\hline Cavaco et al. (2011) [49] & 2 & 2 & 2 & 0 & 1 & 2 & 0 & 0 & 0 \\
\hline $\begin{array}{l}\text { Pichardo-Lowden et al. } \\
\text { (2011) [20] }\end{array}$ & 1 & 1 & 1 & 0 & 1 & 0 & 0 & 1 & NA \\
\hline $\begin{array}{l}\text { Frank-Raue et al. (2011) } \\
\text { [50] }\end{array}$ & 7 & 11 & 9 & 1 & 1 & 3 & 8 & 0 & 2 \\
\hline Cascón et al. (2011) [10] & 1 & 3 & NA & NA & NA & 0 & 3 & NA & NA \\
\hline Siu et al. (2011) [51] & 2 & 2 & 2 & 0 & 0 & 1 & 0 & 0 & NA \\
\hline $\begin{array}{l}\text { Domingues et al. (2012) } \\
\text { [52] }\end{array}$ & 1 & 1 & 1 & 0 & 0 & 0 & 0 & 0 & NA \\
\hline $\begin{array}{l}\text { Guerrouani et al. (2013) } \\
\text { [53] }\end{array}$ & 1 & 1 & 1 & 0 & NA & 0 & 1 & NA & NA \\
\hline Bricaire et al. (2013) [21] & NA & 19 & NA & NA & NA & 5 & 4 & 4 & 6 \\
\hline Kutcher et al. (2013) [54] & 1 & 1 & 0 & 1 & 0 & 1 & 1 & 1 & NA \\
\hline $\begin{array}{l}\text { Ghemigian et al. (2013) } \\
\text { [55] }\end{array}$ & 1 & 3 & 3 & 0 & 0 & 0 & 0 & NA & NA \\
\hline Abdulla et al. (2013) [56] & 1 & 1 & 0 & 1 & 1 & 0 & 1 & NA & NA \\
\hline Pazienza et al. (2013) [57] & 3 & 7 & 7 & 0 & 0 & 0 & 0 & 1 & 1 \\
\hline Kong et al. (2014) [58] & 1 & 2 & 0 & 2 & 1 & 0 & 1 & NA & 2 \\
\hline Chiofalo et al. (2014) [59] & 1 & 2 & 2 & 0 & 0 & 1 & 1 & 0 & NA \\
\hline $\begin{array}{l}\text { Korpi-Hyövälti et al. } \\
\text { (2014) [60] }\end{array}$ & 1 & 7 & NA & NA & NA & 2 & NA & 2 & NA \\
\hline $\begin{array}{l}\text { Sriphrapradang et al. } \\
\text { (2014) [61] }\end{array}$ & 1 & 1 & 1 & 0 & NA & 1 & 1 & 0 & NA \\
\hline Mehta $^{a}$ et al. (2014) [62] & 7 & 16 & 11 & 5 & 4 & 6 & 2 & 3 & 2 \\
\hline Parfitt et al. (2015) [63] & 1 & 1 & 1 & 0 & 0 & 1 & 1 & 0 & 0 \\
\hline Shibata et al. (2015) [64] & 1 & 1 & 1 & 0 & 1 & 0 & 0 & 0 & 0 \\
\hline
\end{tabular}


TABLE 1: Continued.

\begin{tabular}{|c|c|c|c|c|c|c|c|c|c|}
\hline Author (year) & $\begin{array}{c}\text { Kindred } \\
\quad(n=)\end{array}$ & $\begin{array}{c}\mathrm{pHPT} \\
(n=)\end{array}$ & $\begin{array}{l}\text { Single-gland } \\
\text { pHPT }(n=)\end{array}$ & $\begin{array}{l}\text { Synchronous } \\
\text { multiglandular } \\
\text { pHPT }(n=)\end{array}$ & $\begin{array}{c}\text { Recurrences } \\
(n=)\end{array}$ & $\begin{array}{c}\text { Parathyroid } \\
\text { carcinoma } \\
(n=)\end{array}$ & $\begin{array}{c}\text { Jaw } \\
\text { tumor } \\
(n=)\end{array}$ & $\begin{array}{c}\text { Renal } \\
\text { lesions } \\
(n) \\
\end{array}$ & $\begin{array}{c}\text { Uterine } \\
\text { lesions } \\
(n)\end{array}$ \\
\hline Khadilkar et al. (2015) [65] & 4 & 6 & 6 & 0 & 2 & 1 & 2 & 3 & 2 \\
\hline $\begin{array}{l}\text { Marchiori et al. (2015) } \\
\text { [66] }\end{array}$ & 1 & 1 & 1 & 0 & 0 & 1 & 1 & 0 & 0 \\
\hline Bellido et al. (2016) [67] & 1 & 1 & 1 & 0 & 0 & 0 & 1 & NA & NA \\
\hline Ennazk et al. (2016) [68] & 1 & 1 & 1 & 0 & 0 & 0 & 1 & NA & NA \\
\hline Mathews et al. (2016) [69] & 1 & 1 & 1 & 0 & 0 & 0 & 1 & NA & NA \\
\hline Mele et al. (2016) [70] & 1 & 1 & 1 & 0 & 1 & 1 & 1 & NA & 0 \\
\hline Piciu et al. (2016) [71] & 1 & 1 & 1 & 0 & 0 & 0 & 1 & 0 & 1 \\
\hline Guarnieri et al. (2017) [72] & 1 & 3 & 3 & 0 & 0 & 1 & 0 & 0 & 1 \\
\hline $\begin{array}{l}\text { Mamedova et al. (2017) } \\
\text { [73] }\end{array}$ & 6 & 6 & 6 & 0 & 1 & 4 & 0 & 0 & 0 \\
\hline $\begin{array}{l}\text { van der Tuin et al. (2017) } \\
\text { [22] }\end{array}$ & 12 & 32 & 32 & 0 & NA & 5 & 6 & 10 & 1 \\
\hline Dhas et al. (2017) [74] & 1 & 1 & 1 & 0 & 0 & 0 & 1 & 0 & 1 \\
\hline $\begin{array}{l}\text { Rubinstein et al. (2017) } \\
\text { [75] }\end{array}$ & 1 & 1 & 1 & 0 & 0 & 0 & 0 & 0 & 1 \\
\hline Koikawa et al. (2018) [76] & 1 & 1 & 1 & 0 & 0 & 0 & 1 & 0 & 1 \\
\hline $\begin{array}{l}\text { Bachmeier et al. (2018) } \\
\text { [77] }\end{array}$ & 1 & 1 & 1 & 0 & 0 & 0 & 0 & 0 & 0 \\
\hline Kapur et al. (2018) [78] & 1 & 1 & 1 & 0 & NA & 1 & 0 & 0 & 0 \\
\hline Ciuffi et al. (2019) [79] & 1 & 1 & 1 & 0 & NA & 1 & 1 & NA & 0 \\
\hline Russo et al. (2019) [80] & 1 & 1 & 1 & 0 & 1 & 1 & 1 & NA & NA \\
\hline Gill et al. (2019) [81] & 13 & 16 & 15 & 1 & 3 & 4 & 1 & NA & NA \\
\hline Iacobone et al. (2019) [82] & 5 & 20 & 19 & 1 & 6 & 3 & 2 & 1 & 14 \\
\hline Total $n=(\%)$ & 154 & 365 & $198(86.1 \%)$ & $32(13.9 \%)$ & $46(20 \%)$ & $84(23 \%)$ & $\begin{array}{c}104 \\
(28.4 \%) \\
\end{array}$ & $\begin{array}{c}57 \\
(15.6 \%)\end{array}$ & $\begin{array}{c}60 \\
(45.1 \%) \\
\end{array}$ \\
\hline
\end{tabular}

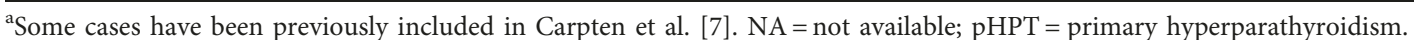

pHPT has not yet been established and remains controversial, varying between bilateral or targeted neck exploration and extensive or limited parathyroidectomy [9].

In the past, prophylactic subtotal or total parathyroidectomy has been suggested to reduce the risk of recurrences and parathyroid carcinoma in HPT-JT syndrome and therefore to obtain a definitive cure; however, total parathyroidectomy is clearly not always successful and leads to an increased morbidity due to the permanent postsurgical hypoparathyroidism that is difficult to treat especially in young patients. For these reasons, subtotal parathyroidectomy or total parathyroidectomy with autotransplantation has been suggested in the same setting of other variants of hereditary pHPT, even if autotransplantation has been advocated to theoretically cause tumor dissemination in case of malignant involvement [82]. Moreover, because of the reported high prevalence of uniglandular involvement at onset, targeted approaches and selective parathyroid excisions have recently been proposed in order to achieve, whenever possible, the longest possible normocalcemia without permanent hypoparathyroidism, minimizing surgical morbidity and facilitating eventual future surgery for recurrent disease [4].

In 2008, Sarquis et al. have observed, in a series of 11 CDC73 germline mutated patients from 3 kindreds, a synchronous multiglandular involvement at initial operation in $54.5 \%$ of cases, parathyroid malignancy in $9 \%$, and an overall persistence/recurrence rate of $80 \%$; thus, a bilateral exploration with subtotal parathyroidectomy was suggested as the initial approach [41].

In 2014, Mehta et al. suggested a bilateral neck exploration with selective removal only of abnormal gland/s in HPT-JT syndrome patients, given the high frequency of benign single-gland involvement $(69 \%)$ and relatively low rate of reoccurences $(20 \%)$ found in their multicentric cohort of 16 individuals from seven families [62].

More recently, Iacobone et al. reported, in a cohort of 20 HPT-JT syndrome patients from five large families, a $95 \%$ rate of single-gland involvement. Therefore, in case of preoperative imaging techniques localizing concordantly, a single-gland involvement and in absence of suspicion of parathyroid malignancy, a focused approach with selective parathyroidectomy has been proposed. In case of absent or discordant preoperative localization, a subtotal parathyroidectomy was suggested because of the increased risk of multiglandular involvement and recurrent pHPT [82]. Regardless of the surgical approach, the risk of recurrences is estimated, according to the review of the literature (Table 1 ), to be about $25 \%$, thus requiring a regular lifelong pHPT biochemical and instrumental monitoring.

If parathyroid carcinoma is clinically suspected (large tumor at imaging, palpable neck mass, and biochemical and clinical presentation of severe $\mathrm{pHPT}$ ), an en bloc resection of the mass with the ipsilateral thyroid lobe, possibly also including the ipsilateral normal parathyroid and the 
surrounding lymph fatty tissue, should be performed, in order to avoid tumor seeding and achieve a "complete unilateral parathyroidectomy," and finally avoiding the risk of reoperation in a scarred area $[4,82-84]$.

Cinacalcet hydrochloride, a calcimimetic that binds to the calcium-sensing receptor, has been approved for the long-term control of hypercalcemia secondary to PHPT in individuals who are unable to undergo parathyroidectomy and for the treatment of parathyroid carcinoma-related hypercalcemia, in case of unresectable or metastatic disease.

For severe or symptomatic hypercalcemia, individuals can be treated with an infusion of zoledronic acid or denosumab for acute management.

3.2. Jaw Tumors. Jaw tumors in HPT-JT are fibro-osseous lesions that typically involve the maxilla or mandible that occur in about $30 \%$ of cases (Table 1), often prior to the third decade of life.

The majority of the reported jaw tumors in HPT-JT syndrome are ossifying fibromas, benign and generally slowgrowing tumors arising from the periodontal ligament in molar or premolar areas [85]. Even if specific features of ossifying fibroma in HPT-JT syndrome are not well defined, most often they appear to be radiographically radiolucent compared to the mixed radiolucent/radiopaque lesions in the sporadic variants [32]. They may present as an enlarging visible or palpable mass, or in some cases, they are only detected on dental X-ray imaging.

Although benign, ossifying fibroma can disrupt normal dentition and impair breathing, causing functional and cosmetic symptoms. Moreover, ossifying fibroma in HPT-JT syndrome may be bilateral/multifocal and may recur. For these reasons, complete surgical removal is the recommended treatment based on the size, location, and symptoms of the lesion. Individuals with a history of jaw tumors should be followed closely because of the possibility of recurrence [86].

3.3. Renal Involvement. The kidney is involved in a limited subset of patients with HPT-JT (approximately 15\% of cases). Cystic kidney disease is the most common renal manifestation of this syndrome.

In addition to renal cysts, some patients often develop hamartomas and rare renal tumors, such as adult Wilms's tumors and mixed epithelial-stromal tumors (MEST). Wilms's tumors in HPT-JT have been identified in the fifth decade of life, are usually bilateral, poorly circumscribed, of smaller sizes compared to the classical childhood form, and they usually do not metastasize. Moreover, they had also distinctive histological features from the childhood form, such as a low number of mitoses, lack of necrosis and hemorrhages, large mesenchymal components, and the presence of cysts [87].

The association between MEST, a predominantly benign tumor characterized by both epithelial and spindle cell stromal components, and HPT-JT syndrome is poorly reported in the literature.
Since HPT-JT patients may be at risk for multiple, bilateral renal tumors potentially requiring multiple renal surgeries over their lifetime, nephron-sparing surgery rather than radical surgery is advocated, in order to preserve renal function [88]. Moreover, given the malignant potential, sarcomatoid differentiation, and metastatic spread, surgery represents the treatment of choice [89].

Papillary renal cell carcinoma have also been described, albeit rarely, in HPT-JT $[4,90]$.

3.4. Uterine Involvement. Uterine tumors have been described in association with HPT-JT and are the most common clinical feature after pHPT, affecting more than $50 \%$ of HPT-JT female patients in some cohorts [9].

Most women present with menorrhagia that may require hysterectomy at an early age (mean 35 years). Affected women often have a history of miscarriage and a significantly impaired ability to bear children when compared with their unaffected female relatives [33]. Histological analysis of the uterine specimens revealed both benign and malignant tumors, such as adenomyosis, adenofibromas, leiomyomas, endometrial hyperplasia, adenosarcomas, or tumors arising from the Müllerian duct system.

No treatment guidelines for uterine manifestations associated with HPT-JT syndrome have been proposed to date. Individuals with evidence of a uterine tumor should be managed by a gynecologist on a case-by-case basis.

3.5. Other Features. Thyroid carcinoma, thyrotoxicosis, colon carcinoma, cholangiocarcinoma, chronic lymphatic leukemia, pancreatic adenocarcinoma, and pituitary cyst have also been described, but the association between these less common tumors and HPT-JT syndrome remains unclear $[4,42,90]$.

3.6. Surveillance. Even if there are no well-established surveillance guidelines, according to the literature we suggest that $C D C 73$ mutation carriers should undergo the following screening:

(i) Biannual evaluation of serum calcium and PTH for pHPT screening, possibly starting at the age of five, and periodic parathyroid ultrasound examination

(ii) Panoramic X-ray dental imaging at least every five years

(iii) Monitor for kidney lesions by periodic renal ultrasound examination, magnetic resonance imaging, or computed tomography scan at least every 5 years, starting at the age of diagnosis

(iv) Starting at the reproductive age, women with a CDC73-related disorder should undergo regular gynecologic care, including pelvic ultrasound examination with eventually further imaging studies if clinically indicated. 


\section{Conflicts of Interest}

The authors declare that there are no conflicts of interest regarding the publication of this paper.

\section{References}

[1] T. Carling and R. Udelsman, "Parathyroid surgery in familial hyperparathyroid disorders," Journal of Internal Medicine, vol. 257, no. 1, pp. 27-37, 2005.

[2] K. J. Bradley, M. R. Hobbs, I. D. Buley et al., "Uterine tumours are a phenotypic manifestation of the hyperparathyroidismjaw tumour syndrome," Journal of Internal Medicine, vol. 257, no. 1, pp. 18-26, 2005.

[3] M. Iacobone, L. Barzon, A. Porzionato et al., "Parafibromin expression, single-gland involvement, and limited parathyroidectomy in familial isolated hyperparathyroidism," Surgery, vol. 142, no. 6, pp. 984-991, 2007.

[4] M. Iacobone, G. Masi, L. Barzon et al., "Hyperparathyroidismjaw tumor syndrome: a report of three large kindred," Langenbeck's Archives of Surgery, vol. 394, no. 5, pp. 817-825, 2009.

[5] G. Masi, L. Barzon, M. Iacobone et al., "Clinical, genetic, and histopathologic investigation of CDC73-related familial hyperparathyroidism," Endocrine Related Cancer, vol. 15, no. 4, pp. 1115-1126, 2008.

[6] G. Masi, M. Iacobone, A. Sinigaglia et al., "Characterization of a new $C D C 73$ missense mutation that impairs parafibromin expression and nucleolar localization," PLoS One, vol. 9, no. 5, Article ID e97994, 2014.

[7] J. D. Carpten, C. M. Robbins, A. Villablanca et al., "HRPT2, encoding parafibromin, is mutated in hyperparathyroidismjaw tumor syndrome," Nature Genetics, vol. 32, no. 4, pp. 676-680, 2002.

[8] T. G. Kelly, T. M. Shattuck, M. Reyes-Mugica et al., "Surveillance for early detection of aggressive parathyroid disease: carcinoma and atypical adenoma in familial isolated hyperparathyroidism associated with a germline HRPT2 mutation," Journal of Bone and Mineral Research, vol. 21, no. 10, pp. 1666-1671, 2006.

[9] M. Iacobone, B. Carnaille, F. Palazzo, and M. Vriens, "Hereditary hyperparathyroidism-a consensus report of the European Society of Endocrine Surgeons (ESES)," Langenbeck's Archives of Surgery, vol. 400, no. 8, pp. 867-886, 2015.

[10] A. Cascón, C. V. Huarte-Mendicoa, L. Javier Leandro-García et al., "Detection of the first gross $C D C 73$ germline deletion in an HPT-JT syndrome family," Genes, Chromosomes and Cancer, vol. 50, no. 11, pp. 922-929, 2011.

[11] A. Porzionato, V. Macchi, L. Barzon et al., "Immunohistochemical assessment of parafibromin in mouse and human tissues," Journal of Anatomy, vol. 209, no. 6, pp. 817-827, 2006.

[12] O. Rozenblatt-Rosen, C. M. Hughes, S. J. Nannepaga et al., "The parafibromin tumor suppressor protein is part of a human Pafl complex," Molecular and Cellular Biology, vol. 25, no. 2, pp. 612-620, 2005.

[13] A. Yart, M. Gstaiger, C. Wirbelauer et al., "The HRPT2 tumor suppressor gene product parafibromin associates with human PAF1 and RNA polymerase II," Molecular and Cellular Biology, vol. 25, no. 12, pp. 5052-5060, 2005.

[14] C. Mosimann, G. Hausmann, and K. Basler, "Parafibromin/ hyrax activates wnt/wg target gene transcription by direct association with $\beta$-catenin/armadillo," Cell, vol. 125 , no. 2 , pp. 327-341, 2006.
[15] P. J. Newey, M. R. Bowl, T. Cranston, and R. V. Thakker, "Cell division cycle protein 73 homolog (CDC73) mutations in the hyperparathyroidism-jaw tumor syndrome (HPT-JT) and parathyroid tumors," Human Mutation, vol. 31, no. 3, pp. 295-307, 2010.

[16] G. V. Walls, M. Stevenson, K. E. Lines et al., "Mice deleted for cell division cycle 73 gene develop parathyroid and uterine tumours: model for the hyperparathyroidism-jaw tumour syndrome," Oncogene, vol. 36, no. 28, pp. 4025-4036, 2017.

[17] F. Cetani, E. Pardi, S. Borsari et al., "Genetic analyses of the HRPT2 gene in primary hyperparathyroidism: germline and somatic mutations in familial and sporadic parathyroid tumors," The Journal of Clinical Endocrinology \& Metabolism, vol. 89, no. 11, pp. 5583-5591, 2004.

[18] L. E. Mallette, S. Malini, M. P. Rappaport, and J. L. Kirkland, "Familial cystic parathyroid adenomatosis," Annals of Internal Medicine, vol. 107, no. 1, pp. 54-60, 1987.

[19] S. M. Hyde, T. A. Rich, S. G. Waguespack, N. D. Perrier, and M. I. Hu, "CDC73-related disorders," in GeneReviews ${ }^{\circledR}$ [Internet], R. A. Pagon, M. P. Adam, H. H. Ardinger et al., Eds., University of Washington, Seattle, WA, USA, 2019.

[20] A. Pichardo-Lowden, A. Manni, B. Saunders, and M. Baker, "Familial hyperparathyroidism due to a germline mutation of the CDC73 gene: implications for management and age-appropriate testing of relatives at risk," Endocrine Practice, vol. 17, no. 4, pp. 602-609, 2011.

[21] L. Bricaire, M.-F. Odou, C. Cardot-Bauters et al., "Frequent large germline HRPT2 deletions in a French national cohort of patients with primary hyperparathyroidism," The Journal of Clinical Endocrinology \& Metabolism, vol. 98, no. 2, pp. E403-E408, 2013.

[22] K. van der Tuin, C. M. J. Tops, M. A. Adank et al., " $C D C 73-$ related disorders: clinical manifestations and case detection in primary hyperparathyroidism," The Journal of Clinical Endocrinology \& Metabolism, vol. 102, no. 12, pp. 4534-4540, 2017.

[23] T. M. Shattuck, S. Välimäki, T. Obara et al., "Somatic and germ-line mutations of the HRPT2 gene in sporadic parathyroid carcinoma," New England Journal of Medicine, vol. 349 , no. 18 , pp. 1722-1729, 2003.

[24] V. M. Howell, C. J. Haven, K. Kahnoski et al., "HRPT2 mutations are associated with malignancy in sporadic parathyroid tumours," Journal of Medical Genetics, vol. 40, no. 9, pp. 657-663, 2003.

[25] W. F. Simonds, C. M. Robbins, S. K. Agarwal, G. N. Hendy, J. D. Carpten, and S. J. Marx, "Familial isolated hyperparathyroidism is rarely caused by germline mutation in HRPT2, the gene for the hyperparathyroidism-jaw tumor syndrome," The Journal of Clinical Endocrinology \& Metabolism, vol. 89, no. 1, pp. 96-102, 2004.

[26] A. Villablanca, A. Calender, L. Forsberg et al., "Germline and de novo mutations in the HRPT2 tumour suppressor gene in familial isolated hyperparathyroidism (FIHP)," Journal of Medical Genetics, vol. 41, no. 3, p. e32, 2004.

[27] B. M. Cavaco, L. Guerra, K. J. Bradley et al., "Hyperparathyroidism-jaw tumor syndrome in Roma families from Portugal is due to a founder mutation of the HRPT2 gene," The Journal of Clinical Endocrinology \& Metabolism, vol. 89, no. 4, pp. 1747-1752, 2004.

[28] V. M. Howell, R. T. Zori, H. J. Stalker et al., "A molecular diagnosis of hyperparathyroidism-jaw tumor syndrome in an adolescent with recurrent kidney stones," The Journal of Pediatrics, vol. 145, no. 4, p. 567, 2004. 
[29] S.-D. Moon, J.-H. Park, E.-M. Kim et al., "A novel IVS2-1G>A mutation causes aberrant splicing of the HRPT2 gene in a family with hyperparathyroidism-jaw tumor syndrome," The Journal of Clinical Endocrinology \& Metabolism, vol. 90, no. 2, pp. 878-883, 2005.

[30] O. Gimm, K. Lorenz, P. Nguyen Thanh et al., "Das familiäre nebenschilddrüsenkarzinom," Der Chirurg, vol. 77, no. 1, pp. 15-24, 2006.

[31] N. Mizusawa, S. Uchino, T. Iwata et al., "Genetic analyses in patients with familial isolated hyperparathyroidism and hyperparathyroidism-jaw tumour syndrome," Clinical Endocrinology, vol. 65, no. 1, pp. 9-16, 2006.

[32] M. J. Aldred, A. A. Talacko, R. Savarirayan et al., "Dental findings in a family with hyperparathyroidism-jaw tumor syndrome and a novel HRPT2 gene mutation," Oral Surgery, Oral Medicine, Oral Pathology, Oral Radiology, and Endodontology, vol. 101, no. 2, pp. 212-218, 2006.

[33] K. J. Bradley, B. M. Cavaco, M. R. Bowl et al., "Parafibromin mutations in hereditary hyperparathyroidism syndromes and parathyroid tumours," Clinical Endocrinology, vol. 64, no. 3, pp. 299-306, 2006.

[34] C. Juhlin, C. Larsson, T. Yakoleva et al., "Loss of parafibromin expression in a subset of parathyroid adenomas," EndocrineRelated Cancer, vol. 13, pp. 509-523, 2006.

[35] V. Guarnieri, A. Scillitani, L. A. Muscarella et al., "Diagnosis of parathyroid tumors in familial isolated hyperparathyroidism with HRPT2 mutation: implications for cancer surveillance," The Journal of Clinical Endocrinology \& Metabolism, vol. 91, no. 8, pp. 2827-2832, 2006.

[36] Y. Yamashita, T. Akiyama, N. Mizusawa, K. Yoshimoto, and M. Goto, "A case of hyperparathyroidism-jaw tumour syndrome found in the treatment of an ossifying fibroma in the maxillary bone," International Journal of Oral and Maxillofacial Surgery, vol. 36, no. 4, pp. 365-369, 2007.

[37] F. Cetani, E. Pardi, E. Ambrogini et al., "Different somatic alterations of the HRPT2 gene in a patient with recurrent sporadic primary hyperparathyroidism carrying an HRPT2 germline mutation," Endocrine-Related Cancer, vol. 14, no. 2, pp. 493-499, 2007.

[38] F. Cetani, E. Ambrogini, P. Viacava et al., "Should parafibromin staining replace HRTP2 gene analysis as an additional tool for histologic diagnosis of parathyroid carcinoma?," European Journal of Endocrinology, vol. 156, no. 5, pp. 547554, 2007.

[39] F. Raue, C. Haag, and K. Frank-Raue, "Hyperparathyreoidismus-kiefertumor-syndrom," DMW-Deutsche Medizinische Wochenschrift, vol. 132, no. 27, pp. 1459-1462, 2007.

[40] F. Cetani, E. Pardi, E. Ambrogini et al., "Hyperparathyroidism 2 gene (HRPT2, CDC73) and parafibromin studies in two patients with primary hyperparathyroidism and uncertain pathological assessment," Journal of Endocrinological Investigation, vol. 31, no. 10, pp. 900-904, 2008.

[41] M. S. Sarquis, L. G. Silveira, F. J. Pimenta et al., "Familial hyperparathyroidism: surgical outcome after 30 years of follow-up in three families with germline HRPT2 mutations," Surgery, vol. 143, no. 5, pp. 630-640, 2008.

[42] V. Guarnieri, M. Bisceglia, N. Bonfitto et al., "Re: familial hyperparathyroidism: surgical outcome after 30 years of follow-up in three families with germline HRPT2 mutations," Surgery, vol. 144, no. 5, pp. 839-840, 2008.

[43] V. M. Howell, A. Gill, A. Clarkson et al., "Accuracy of combined protein gene product 9.5 and parafibromin markers for immunohistochemical diagnosis of parathyroid carcinoma," The Journal of Clinical Endocrinology \& Metabolism, vol. 94, no. 2, pp. 434-441, 2009.

[44] L. G. Silveira, E. P. Dias, B. C. G. Marinho, R. S. Gomez, L. De Marco, and M. S. Sarquis, "HRPT2-related familial isolated hyperparathyroidism: could molecular studies direct the surgical approach?," Arquivos Brasileiros de Endocrinologia \& Metabologia, vol. 52, no. 8, pp. 1211-1220, 2008.

[45] B. P. Schmidt, J. P. Bradrick, and A. Gabali, "Hyperparathyroidism-jaw tumor syndrome: a case report," Journal of Oral and Maxillofacial Surgery, vol. 67, no. 2, pp. 423-427, 2009.

[46] N. Rekik, B. Ben Naceur, M. Mnif et al., "Hyperparathyroidism-jaw tumor syndrome: a case report," Annales d'Endocrinologie, vol. 71, no. 2, pp. 121-126, 2010.

[47] L. M. Panicker, J.-H. Zhang, P. K. Dagur, M. J. Gastinger, and W. F. Simonds, "Defective nucleolar localization and dominant interfering properties of a parafibromin L95P missense mutant causing the hyperparathyroidism-jaw tumor syndrome," Endocrine-Related Cancer, vol. 17, no. 2, pp. 513-524, 2010.

[48] B. Veiguela, M. L. Isidro, S. Jorge, and B. Ruano, "Una causa rara de hipercalcemia: carcinoma sincrónico de dos paratiroides en el contexto del síndrome de hiperparatiroidismo familiar-tumor mandibular," Endocrinología y Nutrición, vol. 57, no. 8, pp. 391-393, 2010.

[49] B. M. Cavaco, R. Santos, A. Félix et al., "Identification of de novo germline mutations in the HRPT2 gene in two apparently sporadic cases with challenging parathyroid tumor diagnoses," Endocrine Pathology, vol. 22, no. 1, pp. 44-52, 2011.

[50] K. Frank-Raue, G. Leidig-Bruckner, A. Lorenz et al., "Hereditäre formen des primären hyperparathyreoidismus," DMW-Deutsche Medizinische Wochenschrift, vol. 136, no. 38, pp. 1889-1894, 2011.

[51] W. K. Siu, C. Y. Law, C. W. Lam et al., "Novel nonsense CDC73 mutations in Chinese patients with parathyroid tumors," Familial Cancer, vol. 10, no. 4, pp. 695-699, 2011.

[52] R. Domingues, R. A. Tomaz, C. Martins, C. Nunes, M. J. Bugalho, and B. M. Cavaco, "Identification of the first germline HRPT2 whole-gene deletion in a patient with primary hyperparathyroidism," Clinical Endocrinology, vol. 76, no. 1, pp. 33-38, 2012.

[53] A. Guerrouani, A. Rzin, and K. El Khatib, "Hyperparathyroidism jaw tumour syndrome detected by aggressive generalized osteitis fibrosa cystica," Clinical Cases in Mineral and Bone Metabolism, vol. 10, no. 1, pp. 65-67, 2013.

[54] M. R. Kutcher, M. H. Rigby, M. Bullock, J. Trites, S. M. Taylor, and R. D. Hart, "Hyperparathyroidism-jaw tumor syndrome," Head \& Neck, vol. 35, no. 6, pp. E175-E177, 2013.

[55] A. Ghemigian, M. Ghemigian, I. Popescu et al., "Familial isolated primary hyperparathyroidism due to HRPT2 mutation," Hormones, vol. 12, no. 3, pp. 454-460, 2013.

[56] A. Abdulla, E. O'Leary, J. Isorena, M. Diaz, and M. Yeh, "Recurrent hyperparathyroidism and a novel nonsense mutation in a patient with hyperparathyriodism-jaw tumor syndrome," Endocrine Practice, vol. 19, no. 6, pp. e134-e137, 2013.

[57] V. Pazienza, A. La Torre, F. Baorda et al., "Identification and functional characterization of three NoLS (nucleolar localisation signals) mutations of the CDC73 gene," PLoS One, vol. 8, no. 12, Article ID e82292, 2013.

[58] J. Kong, O. Wang, M. Nie et al., "Familial isolated primary hyperparathyroidism/hyperparathyroidism-jaw tumour syndrome caused by germline gross deletion or point mutations of CDC73 gene in Chinese," Clinical Endocrinology, vol. 81, no. 2, pp. 222-230, 2014.

[59] M. G. Chiofalo, A. Sparaneo, M. Chetta et al., "A novel CDC73 gene mutation in an Italian family with hyperparathyroidism- 
jaw tumour (HPT-JT) syndrome," Cellular Oncology, vol. 37, no. 4, pp. 281-288, 2014.

[60] E. Korpi-Hyövälti, T. Cranston, E. Ryhänen et al., "CDC73 intragenic deletion in familial primary hyperparathyroidism associated with parathyroid carcinoma," The Journal of Clinical Endocrinology \& Metabolism, vol. 99, no. 9, pp. 3044-3048, 2014.

[61] C. Sriphrapradang, P. Sornmayura, N. Chanplakorn, O. Trachoo, P. Sae-Chew, and R. Aroonroch, "Fine-needle aspiration cytology of parathyroid carcinoma mimic hürthle cell thyroid neoplasm," Case Reports in Endocrinology, vol. 2014, Article ID 680876, 7 pages, 2014.

[62] A. Mehta, D. Patel, A. Rosenberg et al., "Hyperparathyroidism-jaw tumor syndrome: results of operative management," Surgery, vol. 156, no. 6, pp. 1315-1325, 2014.

[63] J. Parfitt, M. Harris, J. M. Wright, and S. Kalamchi, “Tumor suppressor gene mutation in a patient with a history of hyperparathyroidism-jaw tumor syndrome and healed generalized osteitis fibrosa cystica: a case report and genetic pathophysiology review," Journal of Oral and Maxillofacial Surgery, vol. 73, no. 1, pp. 194.e1-194.e9, 2015.

[64] Y. Shibata, M. Yamazaki, M. Takei, S. Uchino, A. Sakurai, and M. Komatsu, "Early-onset, severe, and recurrent primary hyperparathyroidism associated with a novel CDC73 mutation," Endocrine Journal, vol. 62, no. 7, pp. 627-632, 2015.

[65] K. S. Khadilkar, S. R. Budyal, R. Kasliwal, A. R. Lila, T. Bandgar, and N. S. Shah, "HRPT2- (CDC73) related hereditary hyperparathyroidism: a case series from Western India," Endocrine Practice, vol. 21, no. 9, pp. 1010-1016, 2015.

[66] É. C. Marchiori, B. A. Isom, and A. T. Indresano, "Management of ossifying fibroma in a suspicious case of hyperparathyroid-jaw tumor syndrome," Craniomaxillofacial Trauma \& Reconstruction, vol. 8, no. 3, pp. 228-233, 2015.

[67] V. Bellido, I. Larrañaga, M. Guimón et al., "A novel mutation in a patient with hyperparathyroidism-jaw tumour syndrome," Endocrine Pathology, vol. 27, no. 2, pp. 142-146, 2016.

[68] L. Ennazk, G. El Mghari, and N. El Ansari, "Jaw tumor in primary hyperparathyroidism is not always a brown tumor," Clinical Cases in Mineral and Bone Metabolism, vol. 13, no. 1, pp. 64-66, 2016.

[69] J. W. Mathews, R. Winchester, N. Alsaygh, A. M. Bartlett, and L. Luttrell, "Hyperparathyroidism-jaw tumor syndrome: an overlooked cause of severe hypercalcemia," The American Journal of the Medical Sciences, vol. 352, no. 3, pp. 302-305, 2016.

[70] M. Mele, L. Rolighed, M. Jespersen et al., "Recurrence of hyperparathyroid hypercalcemia in a patient with the HRPT-2 mutation and a previous parathyroid carcinoma in hyperparathyroidism-jaw tumor syndrome," International Journal of Endocrinology and Metabolism, vol. 14, no. 2, Article ID e35424, 2016.

[71] D. Piciu, A. Piciu, E. Barbus, C. Pestean, M. I. Larg, and B. Fetica, "Primary hyperparathyroidism-jaw tumor syndrome: a confusing and forgotten diagnosis," Medicine and Pharmacy Reports, vol. 89, no. 4, pp. 555-558, 2016.

[72] V. Guarnieri, R. M. Seaberg, C. Kelly et al., "Large intragenic deletion of $C D C 73$ (exons 4-10) in a three-generation hyperparathyroidism-jaw tumor (HPT-JT) syndrome family," BMC Medical Genetics, vol. 18, no. 1, p. 83, 2017.

[73] E. Mamedova, N. Mokrysheva, E. Vasilyev et al., "Primary hyperparathyroidism in young patients in Russia: high frequency of hyperparathyroidism-jaw tumor syndrome," Endocrine Connections, vol. 6, no. 8, pp. 557-565, 2017.

[74] M. P. R. Dhas, K. S. Karthiga, J. E. Tatu, and S. J. Eugenia, "Hyper parathyroidisim jaw tumor syndrome: a rare condition of incongruous features," Ethiopian Journal of Health Sciences, vol. 27, no. 3, pp. 309-313, 2017.

[75] J. C. Rubinstein, S. K. Majumdar, W. Laskin et al., "Hyperparathyroidism-jaw tumor syndrome associated with largescale 1q31 deletion," Journal of the Endocrine Society, vol. 1, no. 7, pp. 926-930, 2017.

[76] K. Koikawa, Y. Okada, H. Mori, M. Kawaguchi, S. Uchino, and Y. Tanaka, "Hyperparathyroidism-jaw tumor syndrome confirmed by preoperative genetic testing," Internal Medicine, vol. 57, no. 6, pp. 841-844, 2018.

[77] C. Bachmeier, C. Patel, P. Kanowski, and K. Sangla, "Should all patients with hyperparathyroidism be screened for a CDC73 mutation?," Endocrinology, Diabetes \& Metabolism Case Reports, vol. 2018, Article ID EDM170164, 2018.

[78] A. Kapur, N. Singh, O. Mete, R. A. Hegele, and I. G. Fantus, "A young male with parafibromin-deficient parathyroid carcinoma due to a rare germline HRPT2/CDC73 mutation," Endocrine Pathology, vol. 29, no. 4, pp. 374-379, 2018.

[79] S. Ciuffi, L. Cianferotti, G. Nesi et al., "Characterization of a novel CDC73 gene mutation in a hyperparathyrodism-jaw tumor patient affected by parathyroid carcinoma in the absence of somatic loss of heterozygosity," Endocrine Journal, vol. 66, no. 4, pp. 319-327, 2019.

[80] M. Russo, G. Borzì, M. Ilenia, F. Frasca, P. Malandrino, and D. Gullo, "Challenges in the treatment of parathyroid carcinoma: a case report," Hormones, vol. 18, no. 3, pp. 325-328, 2019.

[81] A. J. Gill, G. Lim, V. K. Y. Cheung et al., "Parafibromindeficient (HPT-JT type, CDC73 mutated) parathyroid tumors demonstrate distinctive morphologic features," The American Journal of Surgical Pathology, vol. 43, no. 1, pp. 35-46, 2019.

[82] M. Iacobone, V. Camozzi, C. Mian et al., "Long-term outcomes of parathyroidectomy in hyperparathyroidism-jaw tumor syndrome: analysis of five families with CDC73 mutations," World Journal of Surgery, 2019.

[83] M. Iacobone, F. Lumachi, and G. Favia, "Up-to-date on parathyroid carcinoma: analysis of an experience of 19 cases," Journal of Surgical Oncology, vol. 88, no. 4, pp. 223-228, 2004.

[84] M. Iacobone, C. Ruffolo, F. Lumachi, and G. Favia, "Results of iterative surgery for persistent and recurrent parathyroid carcinoma," Langenbeck's Archives of Surgery, vol. 390, no. 5, pp. 385-390, 2005.

[85] J. D. Chen, C. Morrison, C. Zhang, K. Kahnoski, J. D. Carpten, and B. T. Teh, "Hyperparathyroidism-jaw tumour syndrome," Journal of Internal Medicine, vol. 253, no. 6, pp. 634-642, 2003.

[86] Y. Teh, D. Y. Hu, T. T. Wang et al., "CDC73 gene mutations in sporadic ossifying fibroma of the jaws," Diagnostic Pathology, vol. 11, no. 1, p. 91, 2016.

[87] J. Szabó, B. Heath, V. M. Hill et al., "Hereditary hyperparathyroidism-jaw tumor syndrome: the endocrine tumor gene HRPT2 maps to chromosome 1q21-q31," American Journal of Human Genetics, vol. 56, pp. 944-950, 1995.

[88] C. D. Vocke, C. J. Ricketts, M. W. Ball et al., " $C D C 73$ germline mutation in a family with mixed epithelial and stromal tumors," Urology, vol. 124, pp. 91-97, 2019.

[89] W. L. Xie, J. Y. Lian, B. Li, X. Y. Tian, and Z. Li, "Mixed epithelial and stromal tumor of kidney with renal vein extension: an unusual case report and review of literature," Histology and Histopathology, vol. 32, no. 4, pp. 361-369, 2017.

[90] C. J. Haven, F. K. Wong, E. W. C. M. van Dam et al., "A genotypic and histopathological study of a large Dutch kindred with hyperparathyroidism-jaw tumor syndrome1," The Journal of Clinical Endocrinology \& Metabolism, vol. 85, no. 4, pp. 1449-1454, 2000. 


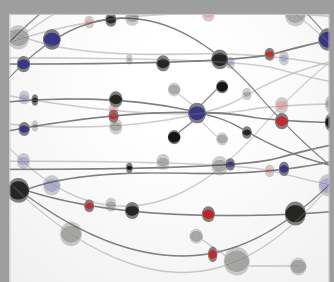

The Scientific World Journal
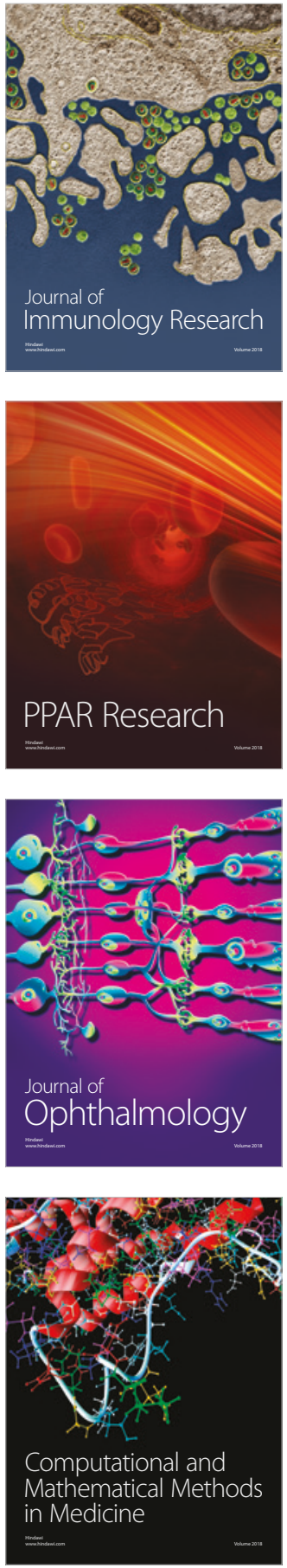

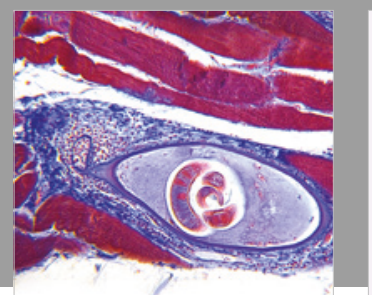

Gastroenterology Research and Practice

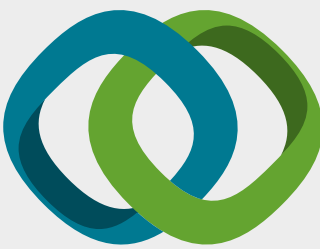

\section{Hindawi}

Submit your manuscripts at

www.hindawi.com
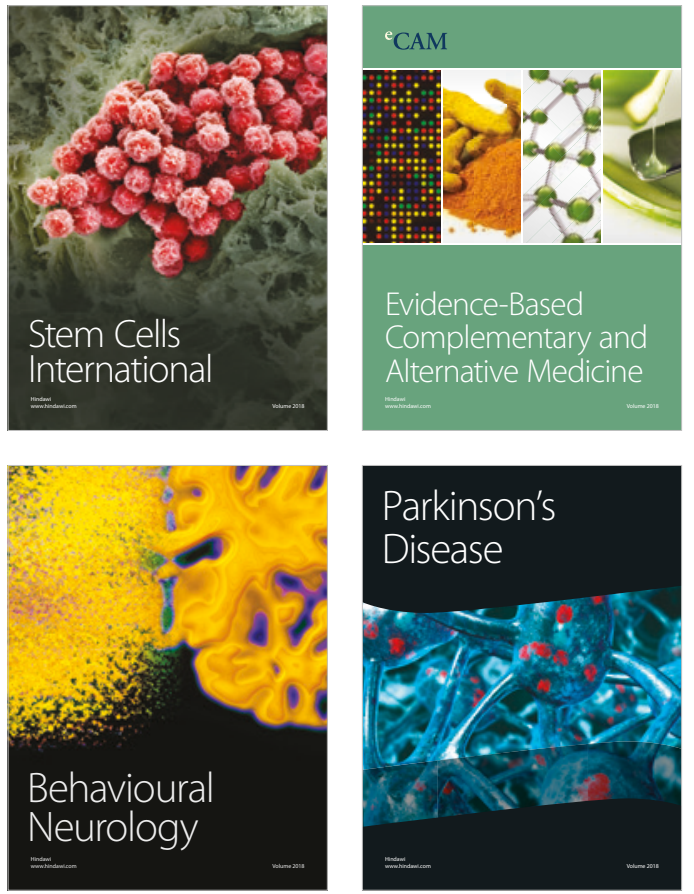

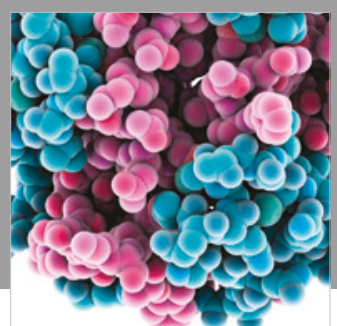

ournal of

Diabetes Research

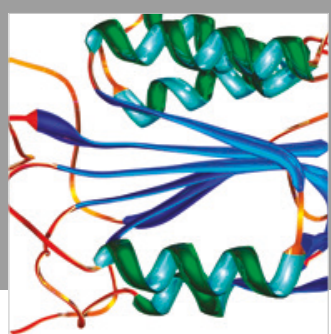

Disease Markers
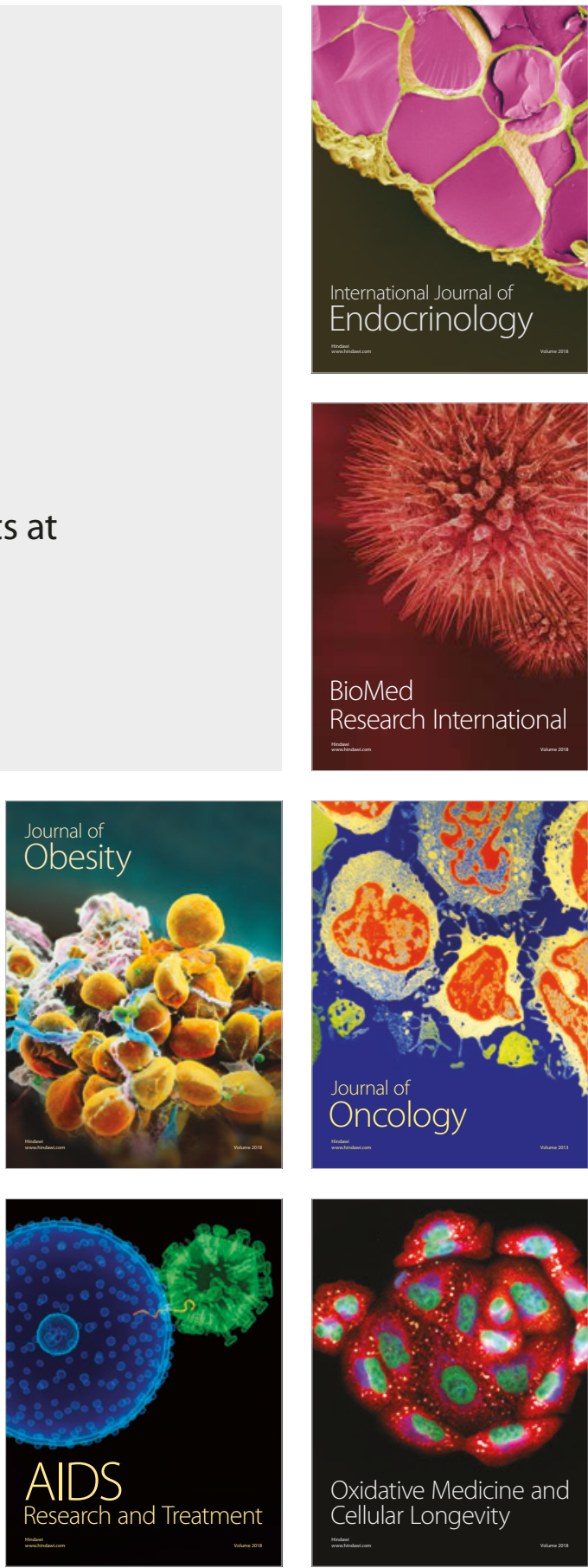